\title{
An Investigation of Various Government Programs, Trade and Industrial Policies on Growth and Development of Small Scale Industries toward Their Marketing Activities in Nigeria
}

\author{
Mufutau Akanbi Awoniyi \\ Department of Marketing, Faculty of Management Sciences, Lagos State University, Lagos, Nigeria \\ Email: mugafric2001@yahoo.com
}

Received 20 October 2014; revised 30 November 2014; accepted 16 December 2014

Copyright (C) 2014 by author and Scientific Research Publishing Inc.

This work is licensed under the Creative Commons Attribution International License (CC BY). http://creativecommons.org/licenses/by/4.0/ (c) (i)

\section{Abstract}

The study examined various government programs, trade and industrial policies and their impacts on survival, growth and development of Small Scale Industry towards their marketing activities in Nigeria with special focus on Lagos State, Nigeria. The purpose of the study was to find out if there is any significant relationship between trade and industrial policies, growth and development of Small Scale Industry and marketing activities in the country. The federal government of Nigeria has over the years shown great interest in development and supports of Small Scale Industries by formulating various programs, trade and industrial policies to stimulate growth and development of SSI and also ensure adequate financing to the sector. Yet, many Small Scale Industries in the country have either packed up, folded up, operating below average capacity or moved to the neighbouring countries for enabling environment. The dependent variable growth and development of Small Scale Industry was characterized into manpower size, business structure, technological development and advancement, among others. While the independent variable, trade and industrial policies were measured using Likert scale. The results revealed that the government trade and industrial policies have little or no effect on growth and development of Small Scale Industries and marketing activities in Nigeria as indicated by the low enhancement of SSIs development on financial assistance of $\mathbf{4 9 \%}$ in Lagos State. The study further showed that government trade and industrial policies have little or no impact on technological development of SSIs in the country as indicated by $\mathbf{9 3 \%}$ of SSIs that started with traditional technology which still maintain $49 \%$ tradition; $7 \%$ semi-mechanized, and $0 \%$ full mechanized/automation. It was concluded that trade and industrial policies of government were formulated with good intention to 
stimulate SSIs development and improve marketing activities of SSIs in the country but bureaucracy, corruption, poor policy implementation and lack of adequate awareness made them very ineffective.

\title{
Keywords
}

\author{
Government Programs, Trade and Industrial Policies, Small and Scale Industries, Growth and \\ Development, Marketing Activities
}

\section{Introduction}

One of the best approaches to stimulate economic growth that will lead to employment generation, poverty alleviation and help in reducing crime in the developing countries such as Nigeria is the encouraging the establishing of Small Scale Industries in the country [1]. Small Scale Industries have played a major role in the development and growth of most of the developed nations and in the developing countries. It has proved to be one of the most viable sectors of the economic with growth potential for development [2]. This is why the government of Nigeria has over the years been formulating policies that will channel investment in the development and growth of Small Scale Industries.

The importance of Small Scale Industries in any of the developing countries cannot be over looked; hence many governments have chosen to intervene by making SSIs to form one of the country's development objectives [3]. There is no universal definition of SSIs. They are defined differently because the parameters used vary from country to country and from sector to sector [4]. In Nigeria, a Small Scale Industry is defined by the National Council on Industry [5] as an enterprise with maximum assets base of N200 million excluding land and working capital and with staff strength of not less than 10 and not more than 300; whose activities include: agro allied; information technology and telecommunication; manufacturing; educational establishment; services; tourism and leisure, among others. The National Economic Reconstruction Fund [6] defines a Small Scale Industry as one whose total assets is less than 10 million naira but made no reference either to its annual turnover or the number of employees. In August 2001, under the Small and Medium Industries Equity Investment Scheme (SMIEIS), a Small Scale Industry is defined as an enterprise with an asset base not exceeding N200 million excluding land and working capital and with a staff strength of not less than 10 and not more than 300 . Under the SMIEIS, Small Scale Industry envelops all types of businesses in nearly all sectors except trading. Small Scale Industry (SSI) has been defined by other scholars as industries which are organized on a small scale and produce goods with the help of small machines with hired labour and power as Small Scale Industries [7].

In achieving the objective of the study, the research focuses on identifying the industrial and trade policies in promoting SSIs in the country; examines the effects of trade and industrial policies of SSIs marketing activities and development; appraise the trade policy in meeting the industrial objectives of the state; and examines the effects of marketing on technological development of SSIs in the country.

The research questions attempted for the study were: Are there government supports for Small Scale Industries development in terms of trade and industrial policies? Does Lagos State Government provide Small Scale Industries with relevant enabling marketing environment such finance, professional advice? The following hypotheses of the study were tested: there is no significant relationship between easier access to necessary inputs by government and development of SSIs; there is no significant relationship between professional advice on marketing/management by government and development of SSIs; there is no significant relationship between government trade and industrial policies and development of SSIs.

The area of study covered was the industrial and commercial zones of Lagos State. In the process of carrying out the research work, some numbers of problems were encountered with particular reference to time, cost constraints, availability of adequate and relevant data/information, lack of data, proper statistical records, in accessibility of data, unwillingness of respondents to cooperate, etc.

\section{Back Ground to the Study}

Over the years, one of the greatest problems confronting business development, market expansion and small 
scale industrial growth is the issue of appropriate trade and industrial policies and focused implementation for SSIs [3]. A number of program and institutions have been created since 1989 to support SSIs development in the country. However, there have been inconsistencies in the implementation of trade and industrial policies and other incentives for SSIs growth.

The federal government of Nigeria has over the year displayed and shown interest in ensuring adequate financing and supports for SSIs by formulating various trade and industrial policies to stimulate growth in that sector. Yet, many SSIs in the country have either packed up or now operating below average capacity. According to Oladele Osu [8] over 12 textiles companies operating along Oshodi-Apapa Express way, in Lagos State alone have completely closed down while not less than 10 trailers of 30 tons capacity of smuggle textiles of various types enter the city of Kano daily from the neighbouring countries. Nigeria, the most populous country in Africa with about 150 million people can't boast of any viable shoe manufacturing company [8]. Bata, Lenard and many notable shoe manufacturing companies/factories in Nigeria have folded up and left long time ago. Some of the Multinational Companies (MNCs) that creates jobs for the establishment of SSIs in the country have either relocated to the neighbouring countries or downsize production.

Lagos State is the industrial and commercial capital of Nigeria with over $60 \%$ of all the industries and commercial activities of the country. The state can't boast of any solid and viable textiles and shoe companies and many of the manufacturing companies in its Industrial Estates-Apapa, Oshodi, Ilupeju, Ikeja, Ikorodu, etc. are operating below average capacity. While, most of the activities provided by entrepreneurs and traders in the Commercial zones of Lagos State are mostly second hand goods and materials (known in Nigeria as "Tokunbos" products).

It has been observed that there is a negative growth on the development of SSIs despite many interventions of government. The study specifically examined government industrial and trade policies in Nigeria and the collapse of many industries in Lagos State.

There are various ways of explaining factors responsible for the collapse of many industries and industrial estates in Lagos State. There are for instance, the contentions that lack of sound and inconsistency of trade and industrial policies and program and poor policy implementation are the major reasons hampering SSIs growth. Others are of the view that lack of enabling environment is factors slowing down SSIs development in the country.

Exploratory research designed was used for the study. Questionnaire was used to supplement data on the issue $\mathrm{s}$ raised in the literature review and conceptual framework. Area sampling technique was used to conduct the survey in the industrial and commercial areas of the state. Information on the Small Scale Industries was obtained from the list of industries in the state. The respondents of the study who were entrepreneurs of the industries were selected from the population frame list of the selected local government consisting of about 2000 SSIs.

\section{Prospect of SSI Development in Nigeria}

Nigeria as a country is blessed with vast resources such as oil gas and solid mineral already confirmed to exist in commercial quantities. The country has potential for enormous power supply, human resources and large population forming a big market and substantial idle capacity in all industrial sectors [9]. Many Small Scale Industries are known to exist in the country since the mid 1980s and have overcome all odds to stay in business over since. This is an indication of great potential for the emergence of a vibrant industrial sector, particularly the small scale segment. A well-focused SSI development program in an investment friendly environment can achieve the long sought industrial transformation which the programme of large scale capital intensive industrialization failed to deliver. The SSI sector can concentrate on the production of raw materials, semi finished goods, machinery, and spare parts, which are the missing middle in the current industrial structure of the country. This can be achieved through the promotion of healthy competition, technology adaptation, sub-contracting arrangement with large companies among others. Also, Small Scale Industries development can be used for achieving the objective of poverty alleviation programme for the government of Nigeria.

The trend towards new business creation will likely continue in the millennium ( $21^{\text {st }}$ century) as more people assume the risks to achieve the personal and professional rewards of running a small business ventures. Success also requires that the entrepreneurs take to heart the valuable lessons learned by others and avoid the mistakes that are so common to many new ventures [10]. Perhaps above all, successful entrepreneurship requires a keen 
understanding of personal assets and limitations and a strong commitment to the challenges.

\section{Marketing Activities}

In 1960 an American Marketing Association Committee defines marketing as "the performance of business activities that direct the flow of goods and services from producer to consumer or user". Phillip Kotler [11] defined marketing as the human activities directed to satisfy human needs and wants through exchange process. Marketing is a process made up of four activities of functions. Marketing activities directed the flow of goods and services from producer to consumers [12]. Marketing activities are:

1) Product activities-developing the "right" product for consumers in order to satisfy them.

2) Pricing activities-determining the appropriate amount of money that will be charged for goods and services.

3) Place activities-making the products to be available where and when needed by consumers.

4) Promotion activities-attempts by marketer to communicate with consumers of the products which include advertising, personal selling, sales promotion, publicity, and public relations.

A very good marketing research and effectively conducted marketing starts with determining what will satisfy the consumers. The marketer then will design and produce consumers' desire product and formulate appropriate price to be charged for that product. The marketer decides how to effectively distribute the products to consumers and how to promote it.

\section{Trade Policy in Nigeria}

When compared to the early 1980, the country has a more open trade policy stance. And there is traditional focus on increasing manufacturing GDP and exports and other macro variables [13]. Nigeria Trade Policy since 1986 has been liberal indicating a deep contrast from that adopted from post independent era. In 1986 two particular importation policy developments were introduced: 1) the institution of a flexible exchange rate mechanism and 2) the adoption of a comprehensive tariff system, which departs from the pre 1987 period in several ways. In the first place, the number of tariff classifications rose from 1560 under 1980 tariff to 4960 . And secondly, the dispersion of tariff rates was reduced and trade weighted normal tariff decline from 33 percent to 23 percent [14].

In 1987, the three import duty surcharges, which were components of the 30 percent consolidated import levy abrogated on the coming into effect of SFEM in September, 1986 were reintroduced. These were the port development surcharge of 5 percent of Nigeria Ports Authority, the Raw Material Research and Development Council surcharge of 1 percent, and the freight rate stabilization surcharge of 0.02 percent of Nigerian Shippers Council.

Furthermore, some items were prohibited. These includes: baby feeding bottles, acid, acid oils from refining and wholly or partly hydro generated or solidified [14].

In 1988, the comprehensive tariff structure, which was aimed at providing a higher degree of protection for local industries and reducing the number of excisable products from 412 to 182, was formally adopted. Also, the harmonized commodity and coding system was incorporated into the new tariff structure. Further, anti-dumping tariff were imposed on roofing sheets, tomato products, aluminium, oil batteries, among others.

In 1989, as a revenue generating measure, a number of products were removed from the import prohibition list and high tariff was imposed on them. These included cigarettes, jewelleries', and precious metals and gaming machines, each of which attracted a zero $(0 \%)$ percent duty. Again, with a view of protecting domestic industries, import duties on some intermediate products used in local industries were reduced e.g., battery part (45 to 20 percent), cold rolled and hot rolled sheets (40 to 20 percent) and tin plated (45 to 20 percent). Duties on some final locally produced goods, such as syringes were raised from 25 to 40 percent, declining annually thereafter to 25 percent in the sixth year. In addition, the duty on enamelware was also raised from 40 to 55 percent, also a decline annually to 40 percent in the sixth year. Other commodities that attracted higher duties included mosquito repellent coils (30 to 200 percent) and motorcycles and bicycles (35 to 45) percent [14].

\section{Policy Objectives of Federal Government}

The objective of government industrial policy shall be to achieve and accelerate pace of industrial development. 
In this regard, the industrial sector would become the prime mover of the economy. The elements of this objective include: 1) Providing greater employment opportunities; 2) Increasing export of manufactured goods; 3) Dispersal of industries; 4) Improving the technological skills and capability available in the country; 5) Increasing local contents of industrial output; 6) Attracting foreign capital and Increase private sector participation in the manufacturing sector [15].

The Nigeria economy in a broader sense is made up of the following: agriculture, crude petroleum, mining and quarrying, commercial and personal services, manufacturing, utilities, building and construction, producers of government services, transport, communication, wholesale and retail trade, hotels and restaurants, finance and insurance, real estate, housing, and others. In Nigeria, the gift of nature distributed over a greater areas of the country, have natural conditions, which favour agriculture and are able to grow product.

\section{Lagos State Industrial Policy}

Lagos State Government as part of its continuing efforts to improve the environment for private sector investment in the state and thereby ensuring that the private sector plays the role expected of it as a major vehicle for the development and growth of the state economy has, after due consultation with the organized private sector, adopted the "Lagos State Industrial Policy" [16].

\section{The Broad Objectives of the Lagos State Industrial Policy}

The broad objectives of the Lagos State Industrial Policy are the attainment of a business climate that attracts, promotes and sustains private sector investment in the state economy especially in the preferred sectors as determined from time to time by government. 1) Integrated rural development and the balanced economic growth and development of the state and 2) the sustenance of the state's premier position as the centre of industrial and commercial activities in the country [16].

\section{The Role of State Government in Industrial and Commercial Activities}

In order to ensure the most efficient allocation of functions and resources, the Lagos State Government shall, as a matter of deliberate policy limits its role into the productive sector primarily to that of a catalyst and a facilitator of private sector investment in the state economy. Accordingly, the state government shall formulate and implement appropriate policy measures that will improve and sustain the investment climate in the state and thereby ensure the continuous increase of private sector investment in the economy. Government shall embark on a deliberate review of all existing legal and administrative practices and procedures in the state which hinder the creation and sustenance of industrial ventures and after due consultation with the relevant bodies in the public and private sectors shall amend or revoke such rules and regulations accordingly [16].

Government, as a matter of deliberate policy shall continue to encourage private investors to participate in such enterprises in the state. In this regard, government shall refrain from participating in such enterprises in such a manner as to put government in the position of a majority or controlling or managing investor. Government's participation in commercial and industrial enterprises will be restricted to that of an investor and all such investments shall be made through the instrumentality of the appropriate state investment agency. Accordingly, government shall, as of deem appropriate, divest itself of controlling interests in commercial and industrial ventures which it owns or has controlling interests. This is without prejudice to government participation in core and strategic areas of the economy as determined by government from time to time. Government shall ensure the commission or reactivation of all identifiable worthwhile government armed or controlled projects through their restructuring in such a manner as to provide the opportunity for the injection of private sector funds and management [16].

\section{Investment Portfolio Management}

To ensure professional and better management of the state's investment, the Ministry of Commerce and Industry shall promote a holding company which shall be the investment agency of government. The company shall be incorporated under the companies decree as a private limited liability company and shall be a profit oriented company and shall be autonomous from government in its day to day operations [16]. 


\section{Provision of Infrastructure and Services}

The state government, recognizing the need to ensure adequate provision of water supply, electricity, telecommunication facilities and a good road network for the purpose of promoting and sustaining the growth and development of agriculture, industry and commerce and raising the productive capacity of the state in general, has over the years achieved notables successes in the provision of these essential facilities. The presence of the existing infrastructure and facilities has been a positive factor in the country. Government is to maintain the existing facilities and shall provide new ones throughout the state [16].

\section{Integrated Rural Development}

As a matter of economic desirability, the need to ensure that parts of the state are developed cannot be over emphasized. The greater part of the land mass of the state is classified as rural. The agriculture and agro-allied industries are rural based and in the main, those parts of the state endowed with the characteristics which attracts tourists developments are located in the rural areas. The promotion and development of commercial and industrial activity in the rural areas is the key component of the state integrated rural development program. For it is only through the integrated development of our rural areas that the state can experience balance economic growth and development state wide.

Government expects the private sector to play a major role in the implementation of the state's rural integral development program, as part of the efforts to sustain developments in the state and ensure balance economic growth and development state wide. Furthermore, government views the implementation of the state's integral rural development program as the major means of reducing urban drift and attaining the dispersal of industries state wide. This will curtail the increasing concentration of people and industries in the urban centres and the consequent demands and pressures on urban centres which if left unchecked will bring about significant diseconomies in the urban areas. Accordingly, government shall continue to provide encouragement and incentives to the private sector, make appropriate investments in ventures with direct and beneficial linkages to the rural areas of the state and collaborate with government in the implementation of the state's integral development program.

In consonance with this policy objective, the Lagos State Government has in addition to the supports and incentives to the agriculture and tourism sectors of the economy, which are considered as preferred sectors for investment, because of their direct and beneficial linkages to rural areas. The incentives consists of generous reduction in land rates for projects in the agricultural sector, the provision at subsidized rates of implements and farming requisites to small scale farmers, the introduction of the graduate farmer scheme and the provision of extension services state wide [16].

\section{Policy on Investment}

In its determined efforts to ensure continued industrial growth, Lagos State Government has established an Investment Promotion Council and Corporate Assembly to provide a forum for mutual co-operation between the organized private sector and the government in economic matters. The government has also established an Industrial Development Finance Company Limited with the sole objective of providing liberalized credit facilities to Small Scale Industries as well as management advisory services. The state government, in collaboration with the federal government and the United Nations Development Program (UNDP) has established a Technology Incubator Centre at Agege, Lagos, reputed to be the first of its kind in West-Africa. The centre provides space and technical experts for technology based Small Scale Industries.

\section{Impact of Trade Policy on Nigeria Economy}

It is expected that trade liberation will leads to greater open door policy of the economy by removing some barriers to trade and altering the incentives structure in favour of trade of goods. The open door system of the economy couple with the liberal incentives structure is expected to encourage the flow of foreign investment into the economy. The entry of foreign companies may influence the productivity of local firms in many ways. Some of these are: 1) The ensuring competition could couple domestic firms to improve their production and management techniques; 2) Local firms may benefit from direct and indirect technology transfer from foreign firms; 3) If new opportunities are created for local companies as a results of the entry of foreign firms, capacity 
utilization may be raised, which may lead to improvement (Appendix Figures A1-5).

\section{Government Incentives to Investors}

In order to sustain investments in the state, promote accelerated development in the rural areas and subsequently create more employment opportunities, the state government provides some incentives to prospective investors. Some of these incentives are: Pioneer Status: This is the provision of Income Tax Relief for Industries that are considered beneficial and strategic to national interest. Such companies are granted tax exemption on corporate income. The relief covers a non-renewable five years for pioneer industries and seven years for those located in economically disadvantaged areas. Tax Relief: Tax relief are available to industrialists who pursue the following: 1) Local raw materials sourcing (Research and Development); 2) Local value added; 3) Intensive labour processes; 4) Non-oil exports; 5) In-plant training (manpower training and development); 6) Investment in economically disadvantaged areas [16].

\section{Liberalization}

In order to promote the policy goals of total liberalization and the private sector led growth of the telecommunications sector, the chairman of the National Council on Privatization (NPC), Vice President Atiku Abubakar, inaugurated a 22 member Telecommunication Sector Reform Implementation Committee (TSRIC) on $1^{\text {st }}$ February, 2000 [17]. The steering committee was to review the existing policy and fine-tune it to enhance domestic and universal acceptability. Liberalization [18] is simply about freedom of participation in any sector of one's choice. Liberalization may then be defined as whole gamut of policies: economic, political or otherwise that leads to increased freedom of choice, equity, fairness and justice. It manifests itself in politics as democracy and in economic world as "openness" i.e. increased competition removal of trade barriers, greater efficiency and minimal government participation in economic activity freedom of participation.

\section{Some Liberalization Policies in Nigeria}

According to Usman [19] released in the CBN Bullion publication of July/Sept. 1999, some liberalization policy were as follow:

- Liberalization of the downstream sector: Aimed at reducing the dependency on NNPC. They will still exist along other independent marketers who wish to market the products. Also there will be the establishment of lots of other refineries.

- Market liberalization: Involves more freely functioning market for foreign exchange, credit and labour; reduced government intervention and regulate of marketing and pricing of traded products; the dismantling of state foreign exchange management and import restrictions; and introduction of more commercial principles into the management of public enterprises.

- Trade liberalization: Consists of the body of economic rules favouring free trade and then determination of wages and prices competition and the market place. It opposes state intervention and the use of tariffs and other barriers. The objectives of trade liberalization are to ensure that barriers to economic development are removed. It also includes the efficient running of enterprises and provision of better services to customers and consequently improvement in the standard of living of populace. Trade liberalization in Nigeria involves reforms in the Structural Adjustment Programme (SAP) aimed at restructuring the service market introduced in 1986.

- Liberalization of the service sector: In the 90's the service sector witnessed an impressive expansion, contributing a large proportion to the Gross Domestic Product (GDP) of several countries.

Services provide complementary consumption; generate auxiliary outputs as inputs for the other sectors; and generally create more employment than any of the other sectors producing tangible goods. Regional reform mechanism can be found in the relevant integration and cooperation arrangements such as the Revised ECOWAS Treaty of 1993, and the EU-ACP Economic Partnership Agreement. There are ten identified components in Nigeria services sectors: Utilities, building and construction, transport, communication, wholesale and retailing business, hotel and restaurant, financial services, real estate, and repairs and other services.

A general liberal investment environment was created with the promulgation of the Nigerian Investment Promotion Commission Decree No. 16 of 1995 and the Foreign Exchange (Monitoring and Miscellaneous Pro- 
vision) (FEMMP) Decree No. 17 of 1995.

- Liberalization of Financial sector: This started in 1987 with a package of interest rate liberalization and easy entry and exit conditions strengthening of prudential guidelines induced by sector-wide reforms; strengthening the financial services sector by providing market alternatives; the free repatriation of profits or capital in the event of sale or liquidation; and the internationalization of the Nigerian capital market. A foreign investor can set up financial services business in Nigeria with 100 percent ownership, in contrast to the earlier ownership limitation to 40 percent.

- Nigerian Communication Commission Decree (NCCD) 75 of 1992 is the main legislation governing the telecommunications sector. The decree liberalized various aspects of telecommunications activities including the installation of terminal or other equipment; provision and operation of public payphones; provision and operation of private network links employing cable, radio communication or satellite exclusively within Nigeria; provision and operation of public mobile communication (GSM standard); provision of community telephones; provision and operation value-added network services; repair and maintenance of telecommunication facilities; and cabling. In 1992 several private operators were licensed to provide mobile telecommunications services using the VSAT technology among others. After 1994, a series of liberalization measures were implemented in the sector. One such measure taken in 1997 was the agreement between NITEL and MCN that authorized the latter company to provide telephone services through the former national grid, breaking NITEL monopoly in basic telecommunications.

Liberalization of the transport sector: In air transport, the private sector operates actively on domestic routes while Nigeria Airways competes with foreign airlines on international routes. In shipping, the Nigerian shipping policy decree was enacted in 1987 with the major objective of increasing the participation of domesticallyowned ships in international trade. The decree places a limit on the number of maritime transport as well as naturalized persons working in the maritime.

\section{Major Problems of Small Scale Industries in Nigeria}

1) Lack of access to credits and loans facilities.

2) High cost of business operations.

3) Bureaucratic bottlenecks and red tape.

4) Double taxation and insecurity.

5) Unhealthy trade practices and poor marketing techniques and practices.

6) Lack of modern equipment and technology to compete favourable.

7) Unsteady power supply and other infrastructure for smooth business operations.

\section{Lagos State Industrial and Commercial Zones}

The area of study covered was the industrial and commercial zones of Lagos State. The state was divided into industrial and commercial zones according to the local government settings. Lagos State has a population of about 15 million people made up of various ethnic groups in Nigeria. The industrial zones of Lagos State are: Ikeja; Apapa; Matori; Oshodi/Isolo, Ilupeju; Victoria Island; Ikoyi; Lekki; etc. The commercial zones of the state are: Mushin; Agege; Badagry; Lagos Island; Ajegunle; Ojo; etc. [3].

\section{Assessment of Industrial Policies on Small Scale Industries-Awareness}

There exist a significant relationship between awareness of different programs and entrepreneurial development because P-value (0.000) is less than 0.05 . There is a positive relationship between awareness of different programmes and entrepreneurial development (Tables A1-7). This implies that more people are aware of the programs, which enhance SSI development.

Assessment of awareness of industrial policies on Small Scale Industries can be generally stated to be between low and very low on small scale enterprises growth.

\section{Hypothesis (Table A6)}

The relationship between industrial policy and development of SSI is positive but no significant relationship because the P-value (0.199) is greater than 0.05 . The industrial policy of government has contributed to develop- 
ment of Small Scale Industries.

The analysis from the distribution of respondents on issues of program on SSI development is between low and very low. And therefore, relationship between industrial policy and SSI development is positive but no significant relationship.

\section{Summary}

The research work focused on assessment of governments industrial policies on the development Small Scale Industries in Lagos State. The research was conducted with a view to find out if there exists any significant relationship between industrial policy of government and development of SSI or not. And also to find out if there is any significant relationship between easier access to necessary input by government, professional advice on management by government and SSI development or not

In order to achieve this aim, relevant literature was reviewed laying more emphasis on industrial policies with special focus on necessary input in form of finance, professional advice or management by government, privatization, liberalization and other programmes of government formulated to assist in the development of SSI.

For collection of data the questionnaire was adopted as the primary source of data. The secondary sources used were textbooks, journals, and magazines relating to the topic as well as information from the Institute for Entrepreneurship, Small Business Administration websites among others. As clearly indicated by the data collected and analyzed, the following results emerged:

- That most of the Small Scale Industries that started with below N50,000 have their capitalization increased to N351,000 to N450,000 after some years of operation.

- That majority of Small Scale Industries still remains and maintains old traditional technology after some years of operation.

- That majority of small scale operators in Lagos State are of male gender.

- That a significant number of small scale entrepreneurs fall between the ages of 38 - 45 years.

- That there exist significant relationship between easier access to necessary inputs by government and development of SSI.

- That there exist a significant relationship between professional advice on management by government and development of SSI.

- That there is no significant relationship between industrial policy and development of SSI but the relationship is positive.

- There is significant relationship between awareness of different programs and development of SSI.

\section{Conclusions}

From various analyses, it was clearly summarized in the research study. The following conclusions can be made:

1) Government industrial policies were formulated with good intention but the implementation bureaucracy and strategic organizing made them ineffective to the people of the grass root.

2) The effects of government industrial policies were being hampered by the poor enabling environment. The poor enabling environment resulted in poor services of electricity, water, bad roads, and insecurity among others.

3) Within the framework of industrial policies, the introduction of some programmes such as establishment of industrial estate, local raw materials sourcing among others has indeed assisted some small scale industrial development in the state. The privatization and liberalization programmes allow some private individuals to venture into some areas of trade exclusively for big companies or government corporations.

4) An average Small Scale Industry in the state does not really rely on government infrastructure of amenities to survive.

5) The present state of the economy does not adequately guarantee survival strategy cover for any of the Small Scale Industries.

6) Enabling environment creates increase in sales for SSIs that leads to market expansion.

\section{References}

[1] Osuagwu, L. (2001) Small Business Entrepreneurship Management. 1st Edition, Grey Resources Limited, Lagos.

[2] Wennekers, S., et al. (1999) Linking Entrepreneurship and Economic Growth Small Business. Economics, 13, 27-55. 
http://dx.doi.org/10.1023/A:1008063200484

[3] Awoniyi, M.A. (2006) An Assessment of State Government Industrial Policies on Small Scale Industry Development in Lagos State, Nigeria. Thesis Dissertation, Obafemi Awolowo University, Ile-Ife.

[4] Osuagwu, L. (2006) Strategic Management Practices in Nigeria Small Business Enterprises. Proceedings of BAI International Conference on Business and Information, Singapore.

[5] National Council on Industry (1996) Small Scale Industry in Nigeria.

[6] National Economic Reconstruction Fund (1989) NERFUND Report Book.

[7] Wiki Answer (2013) Internet Accessed Report.

[8] Oladele, O. (2012) Small and Medium Industrial Operations. Manufacturer Association of Nigeria (MAN).

[9] Central Bank of Nigeria (2000) Annual Report and Statement of Account. CBN, Abuja.

[10] Czinkota, M.R. (1999) International Business. 5th Edition, The Dryden Press, Chicago.

[11] Kotler, P. (1972) A Generic Concept of Marketing. Journal of Marketing, 36, 46-54.

[12] Schewe, C.D. (1987) Marketing: Principles and Strategies. Random House Inc., New York.

[13] Manson, N. (2001) Trade Liberalization and Poverty in Nigerian: Lessons from the Past. African Institute for Applied Economics, Lagos.

[14] Trade Policy Reviews (2000) First Release, Secretariat and Government.

[15] Obitayo, K.M. (2001) Government's Industrial Policies in Respect of Small and Medium Enterprises in Nigeria. Vol. 15, Central Bank of Nigeria’s Bullion, Abuja.

[16] (1999) Lagos State Investors Guide.

[17] Mohammed, A. (2000) Nigeria Telecommunication Policy. National Policy on Telecommunication, September 2000.

[18] Olomola, A., et al. (1996) Market Liberalization and Its Effects on Nigerian Agriculture. National Research Network on Liberalization Policies in Nigeria, NISER/SSCN, Lagos, Working Paper No. 16.

[19] Usman, S. (1999) Planning and Phasing the Privatization of Public Enterprises in Nigeria: The Second Phase. CBN Bullion Publication, Abuja.

\section{Definition of Terms}

NIDB-Nigeria Industrial Development Bank

NERFUND-National Economic Reconstruction Funds

IDC-Industrial Support Centres

BSC_Business Support Centres

SSCIS-Small Scale Industrial Credit Scheme

SSI-Small Scale Industry

FEAP_Family Economic Development Programme

PBN-People Bank of Nigeria

BLP_Better Life Programme

FSP_Family Support Programme

SMIESIS-Small and Medium Industries Equity Investment Scheme

SMEDAN_Small and Medium Enterprises Development Agency of Nigeria 


\section{Appendix}

Industrial Policy

- The Lagos state government policy on SSI focus on the following;

- Policy on finance-easier access to necessary inputs, liberalized credit facilities to SSI and provision of market alternatives

- Management-professional advice on management.

- Advice on running of commercial ventures

- Industrial estates. Establishment of new industrial estate and areas throughout the state

Other policies affecting SSI

- Industrial land: To ensure that land earmarked for commercial and industrial purposes are preserved and used solely for such purposes.

- Integrated rural development-government to ensure balanced economic growth and development state wide by carving out areas for establishment of new industrial estate throughout the state.

- Policy on investment-establishment of Investment Promotion Council and Corporate Assembly to provide forum for mutual cooperation.

- Market liberalization and privatization

Figure A1. Schematic diagram of industrial policy influencing the development of SSI in Nigeria. Source: [3].

Distribution of respondent by program awareness

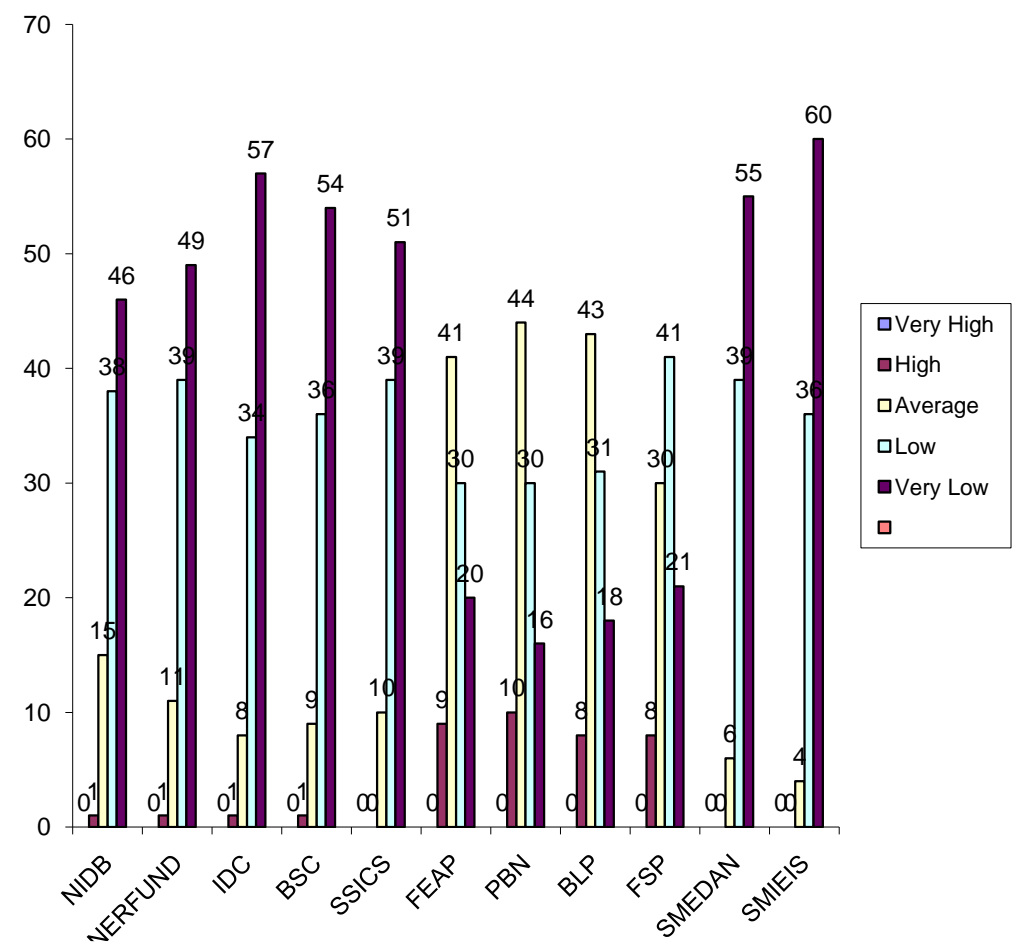

Figure A2. Distribution of respondent by programme awareness. Source: [3]. 
Distribution of respondents by program enhancement of SSI growth

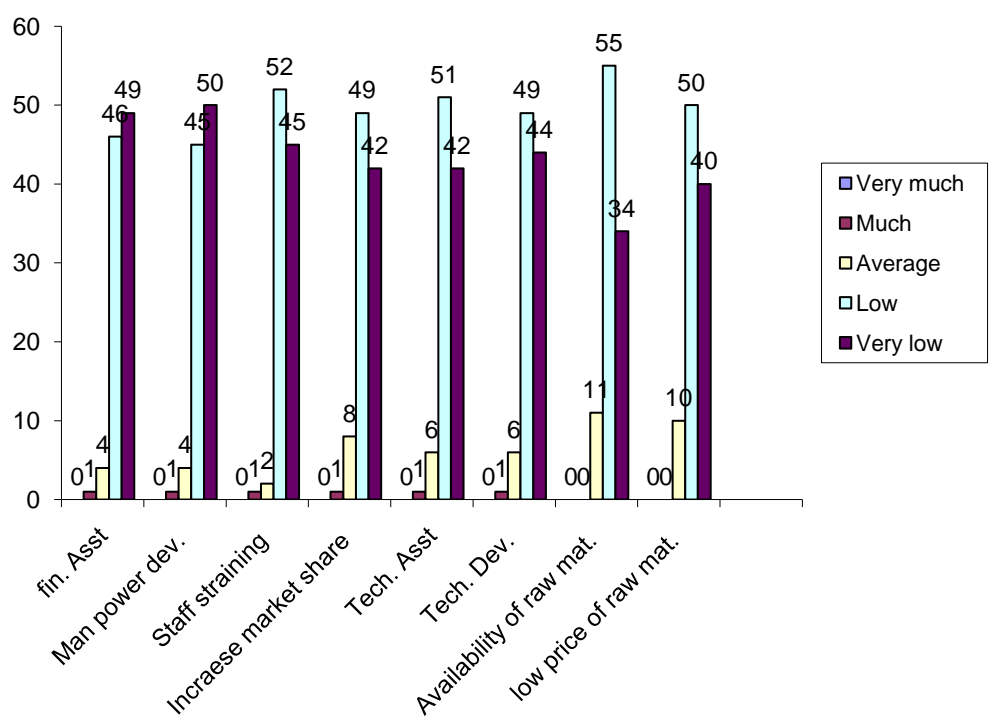

Figure A3. Distribution of respondents by program enhancement of enterprises. Source: [3].

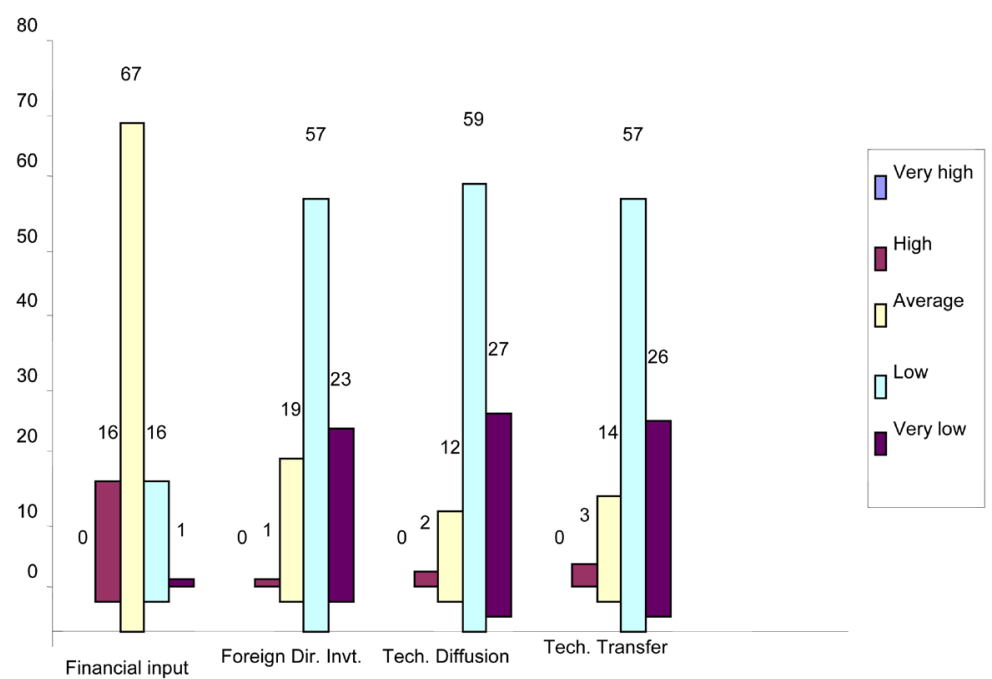

Figure A4. Distribution of respondents on access to input program on SSI growth. Source: [3].

Distribution of respondent on liberalization programs

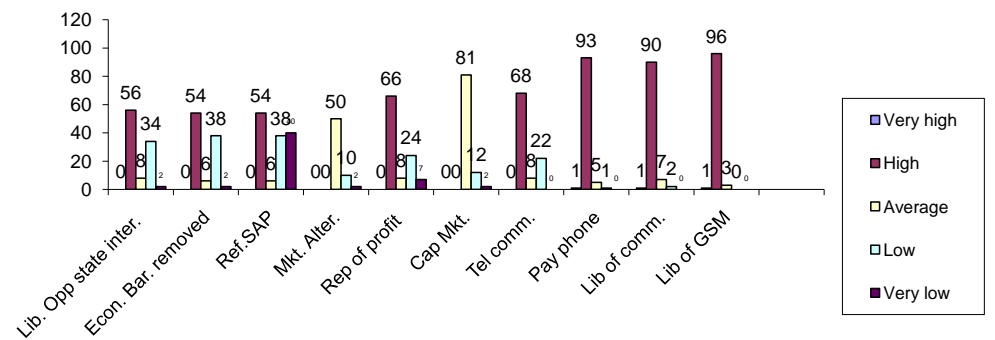

Figure A5. Distribution of respondent on liberalization programs. Source: [3]. 
Table A1. Industrial programme.

\begin{tabular}{|c|c|c|c|c|c|c|c|c|c|c|}
\hline \multicolumn{11}{|c|}{ Distribution of respondents on programs awareness } \\
\hline \multirow{2}{*}{ Awareness } & \multicolumn{2}{|c|}{ Very high } & \multicolumn{2}{|c|}{ High } & \multicolumn{2}{|c|}{ Average } & \multicolumn{2}{|c|}{ Low } & \multicolumn{2}{|c|}{ Very low } \\
\hline & $\mathrm{F}$ & $\%$ & $\mathrm{~F}$ & $\%$ & $\mathrm{~F}$ & $\%$ & $\mathrm{~F}$ & $\%$ & $\mathrm{~F}$ & $\%$ \\
\hline NIDB & 0 & 0 & 2 & 8 & 22 & 15 & 57 & 38 & 69 & 46 \\
\hline NERFUND & 0 & 0 & 2 & 1.3 & 16 & 11 & 59 & 39 & 73 & 49 \\
\hline IDC & 0 & 0 & 2 & 1.3 & 12 & 8 & 51 & 34 & 85 & 57 \\
\hline BSC & 0 & 0 & 2 & 1.3 & 13 & 9 & 54 & 36 & 81 & 54 \\
\hline SSCIS & 0 & 0 & 0 & 0 & 15 & 10 & 58 & 39 & 77 & 51 \\
\hline FEAP & 0 & 0 & 13 & 9 & 62 & 41 & 45 & 30 & 30 & 20 \\
\hline PBN & 0 & 0 & 15 & 10 & 66 & 44 & 45 & 30 & 24 & 16 \\
\hline BLP & 0 & 0 & 12 & 8 & 64 & 43 & 47 & 31 & 27 & 18 \\
\hline FSP & 0 & 0 & 12 & 8 & 45 & 30 & 62 & 42 & 31 & 21 \\
\hline SMEDAN & 0 & 0 & 4 & 3 & 9 & 6 & 59 & 39 & 78 & 52 \\
\hline SMIESIS & 0 & 0 & 5 & 3 & 85 & 57 & 54 & 36 & 6 & 4 \\
\hline
\end{tabular}

Source: [3].

Table A2. Distribution of respondents on issues of programmes SSI development.

\begin{tabular}{|c|c|c|c|c|c|c|c|c|c|c|}
\hline \multirow{2}{*}{ Issues of programs } & \multicolumn{2}{|c|}{ Very much } & \multicolumn{2}{|c|}{ Much } & \multicolumn{2}{|c|}{ Average } & \multicolumn{2}{|c|}{ Low } & \multicolumn{2}{|c|}{ Very low } \\
\hline & $\mathrm{F}$ & $\%$ & $\mathrm{~F}$ & $\%$ & $\mathrm{~F}$ & $\%$ & $\mathrm{~F}$ & $\%$ & $\mathrm{~F}$ & $\%$ \\
\hline Political climate & 0 & 0 & 0 & 0 & 7 & 5 & 68 & 45 & 75 & 50 \\
\hline SSI education & 0 & 0 & 0 & 0 & 7 & 5 & 69 & 46 & 74 & 49 \\
\hline SSI value & 0 & 0 & 0 & 0 & 15 & 10 & 67 & 45 & 68 & 45 \\
\hline SSI incubation & 0 & 0 & 0 & 0 & 5 & 3 & 64 & 43 & 81 & 54 \\
\hline SSI start up & 0 & 0 & 0 & 0 & 5 & 3 & 81 & 54 & 64 & 43 \\
\hline
\end{tabular}

Source: [3].

Table A3. Industrial programmes.

\begin{tabular}{|c|c|c|c|c|c|c|c|c|c|c|}
\hline \multirow{3}{*}{ Programs } & \multicolumn{10}{|c|}{ Distribution of respondents on issues of enhancements SSI development } \\
\hline & \multicolumn{2}{|c|}{ Very much } & \multicolumn{2}{|c|}{ Much } & \multicolumn{2}{|c|}{ Average } & \multicolumn{2}{|c|}{ Low } & \multicolumn{2}{|c|}{ Very low } \\
\hline & $\mathrm{F}$ & $\%$ & $\mathrm{~F}$ & $\%$ & $\mathrm{~F}$ & $\%$ & $\mathrm{~F}$ & $\%$ & $\mathrm{~F}$ & $\%$ \\
\hline Fin assistance & 0 & 0 & 2 & 1 & 6 & 4 & 69 & 46 & 73 & 49 \\
\hline Manpower development & 0 & 0 & 2 & 1 & 6 & 4 & 67 & 45 & 75 & 50 \\
\hline Staff training & 0 & 0 & 2 & 1 & 3 & 2 & 78 & 52 & 67 & 45 \\
\hline Increase market share & 0 & 0 & 2 & 1 & 12 & 8 & 73 & 49 & 63 & 42 \\
\hline
\end{tabular}

Source: [3].

Table A4. Distribution of Respondents on Issues of SSI growth.

\begin{tabular}{|c|c|c|c|c|c|c|c|c|c|c|}
\hline \multicolumn{11}{|c|}{ TECHNICAL } \\
\hline Technical assistance & 0 & 0 & 2 & 1 & 9 & 6 & 76 & 51 & 63 & 42 \\
\hline Technological development & 0 & 0 & 2 & 1 & 9 & 6 & 73 & 49 & 66 & 44 \\
\hline Availability of raw materials & 0 & 0 & 0 & 0 & 16 & 11 & 83 & 55 & 51 & 34 \\
\hline Lower price of raw materials & 0 & 0 & 0 & 0 & 15 & 10 & 75 & 50 & 60 & 40 \\
\hline
\end{tabular}

Source: [3]. 
Table A5. Distribution of respondents on access to input program on SSI growth.

\begin{tabular}{|c|c|c|c|c|c|c|c|c|c|c|}
\hline \multirow{2}{*}{ Access to input } & \multicolumn{2}{|c|}{ Very high } & \multicolumn{2}{|c|}{ High } & \multicolumn{2}{|c|}{ Average } & \multicolumn{2}{|c|}{ Low } & \multicolumn{2}{|c|}{ Very low } \\
\hline & $\mathrm{F}$ & $\%$ & $\mathrm{~F}$ & $\%$ & $\mathrm{~F}$ & $\%$ & $\mathrm{~F}$ & $\%$ & $\mathrm{~F}$ & $\%$ \\
\hline Financial input & 0 & 0 & 24 & 16 & 100 & 67 & 24 & 16 & 2 & 1 \\
\hline Foreign direct investment & 0 & 0 & 2 & 1 & 28 & 19 & 85 & 57 & 35 & 23 \\
\hline Technological diffusion & 0 & 0 & 3 & 2 & 18 & 12 & 88 & 59 & 41 & 27 \\
\hline Technological transfer & 0 & 0 & 5 & 3 & 21 & 14 & 85 & 57 & 39 & 26 \\
\hline
\end{tabular}

Source: [3].

Table A6. Relationship between SSI developments.

\begin{tabular}{ccc}
\hline 1 & Easier access to necessary input by government & $0.203^{*}(0.043)$ \\
2 & Professional advice on management by government & $0.326^{* *}(0.001)$ \\
3 & Industrial policy & $0.130(0.199)$ \\
\hline
\end{tabular}

Note: ${ }^{*}$ Significant at $0.05 ;{ }^{* *}$ Significant at 0.001 . Source: [3].

Table A7. Industrial programmes.

\begin{tabular}{|c|c|c|c|c|c|c|c|c|c|c|}
\hline \multicolumn{11}{|c|}{ Distribution of respondents on liberalization programs } \\
\hline \multirow{2}{*}{ Liberalization program } & \multicolumn{2}{|c|}{ Strongly agree } & \multicolumn{2}{|c|}{ Agree } & \multicolumn{2}{|c|}{ Neutral } & \multicolumn{2}{|c|}{ Disagree } & \multicolumn{2}{|c|}{ Strongly disagree } \\
\hline & $\mathrm{F}$ & $\%$ & $\mathrm{~F}$ & $\%$ & $\mathrm{~F}$ & $\%$ & F & $\%$ & $\mathrm{~F}$ & $\%$ \\
\hline Liberalization of NNPC & 0 & 0 & 124 & 83 & 5 & 3 & 15 & 10 & 6 & 4 \\
\hline Free functioning market & 0 & 0 & 102 & 68 & 6 & 4 & 39 & 26 & 3 & 2 \\
\hline Reducing govt. intervention & 0 & 0 & 91 & 61 & 5 & 3 & 49 & 33 & 5 & 3 \\
\hline Dismantling state foreign exchange & 0 & 0 & 87 & 58 & 15 & 10 & 39 & 26 & 9 & 6 \\
\hline More commercial principles & 0 & 0 & 96 & 64 & 7 & 5 & 44 & 29 & 3 & 2 \\
\hline Favouring free trade & 0 & 0 & 90 & 60 & 10 & 7 & 48 & 32 & 2 & 1 \\
\hline \multirow{2}{*}{ Liberalization program } & \multicolumn{2}{|c|}{ Strongly agree } & \multicolumn{2}{|c|}{ Agree } & \multicolumn{2}{|c|}{ Neutral } & \multicolumn{2}{|c|}{ Disagree } & \multicolumn{2}{|c|}{ Strongly disagree } \\
\hline & $\mathrm{F}$ & $\%$ & $\mathrm{~F}$ & $\%$ & $\mathrm{~F}$ & $\%$ & $\mathrm{~F}$ & $\%$ & $\mathrm{~F}$ & $\%$ \\
\hline $\begin{array}{l}\text { Liberalization opposes state } \\
\text { intervention }\end{array}$ & 0 & 0 & 84 & 56 & 12 & 8 & 51 & 34 & 3 & 2 \\
\hline $\begin{array}{l}\text { Liberalization to ensure barrier to } \\
\text { economic development are removed }\end{array}$ & 0 & 0 & 81 & 54 & 9 & 6 & 57 & 38 & 3 & 2 \\
\hline Liberalization reforming SAP & 0 & 0 & 0 & 0 & 75 & 50 & 15 & 10 & 60 & 40 \\
\hline $\begin{array}{l}\text { Liberalization proving market } \\
\text { alternatives }\end{array}$ & 0 & 0 & 99 & 66 & 12 & 8 & 36 & 24 & 3 & 2 \\
\hline Liberalization repatriation of profit & 0 & 0 & 0 & 0 & 121 & 81 & 14 & 12 & 11 & 7 \\
\hline Liberalization inter. of capital market & 0 & 0 & 102 & 68 & 12 & 8 & 33 & 22 & 3 & 2 \\
\hline Liberalization of tel. comm. & 1 & 1 & 134 & 89 & 8 & 5 & 8 & 5 & 0 & 0 \\
\hline Liberalization of pay phone & 1 & 1 & 140 & 93 & 8 & 5 & 2 & 1 & 0 & 0 \\
\hline Liberalization of comm. & 2 & 1 & 135 & 90 & 10 & 7 & 3 & 2 & 0 & 0 \\
\hline Liberalization of GSM & 2 & 1 & 144 & 96 & 4 & 3 & 0 & 0 & 0 & 0 \\
\hline
\end{tabular}

Source: [3]. 
Scientific Research Publishing (SCIRP) is one of the largest Open Access journal publishers. It is currently publishing more than 200 open access, online, peer-reviewed journals covering a wide range of academic disciplines. SCIRP serves the worldwide academic communities and contributes to the progress and application of science with its publication.

Other selected journals from SCIRP are listed as below. Submit your manuscript to us via either submit@scirp.org or Online Submission Portal.
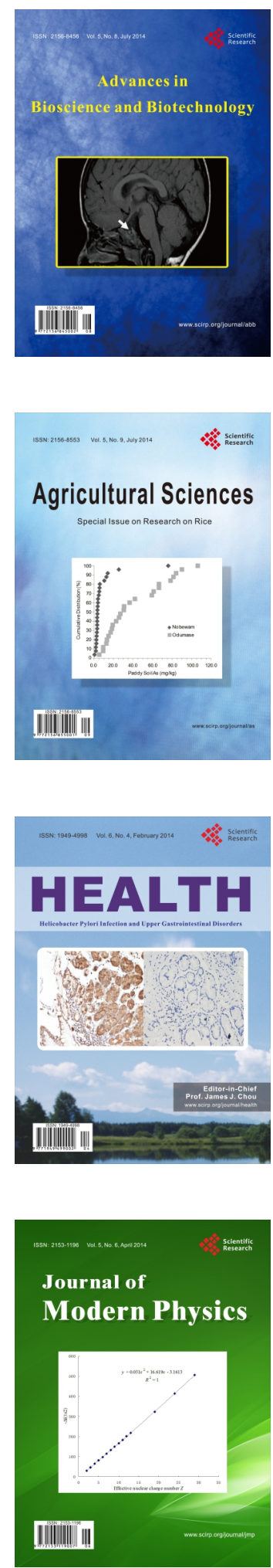
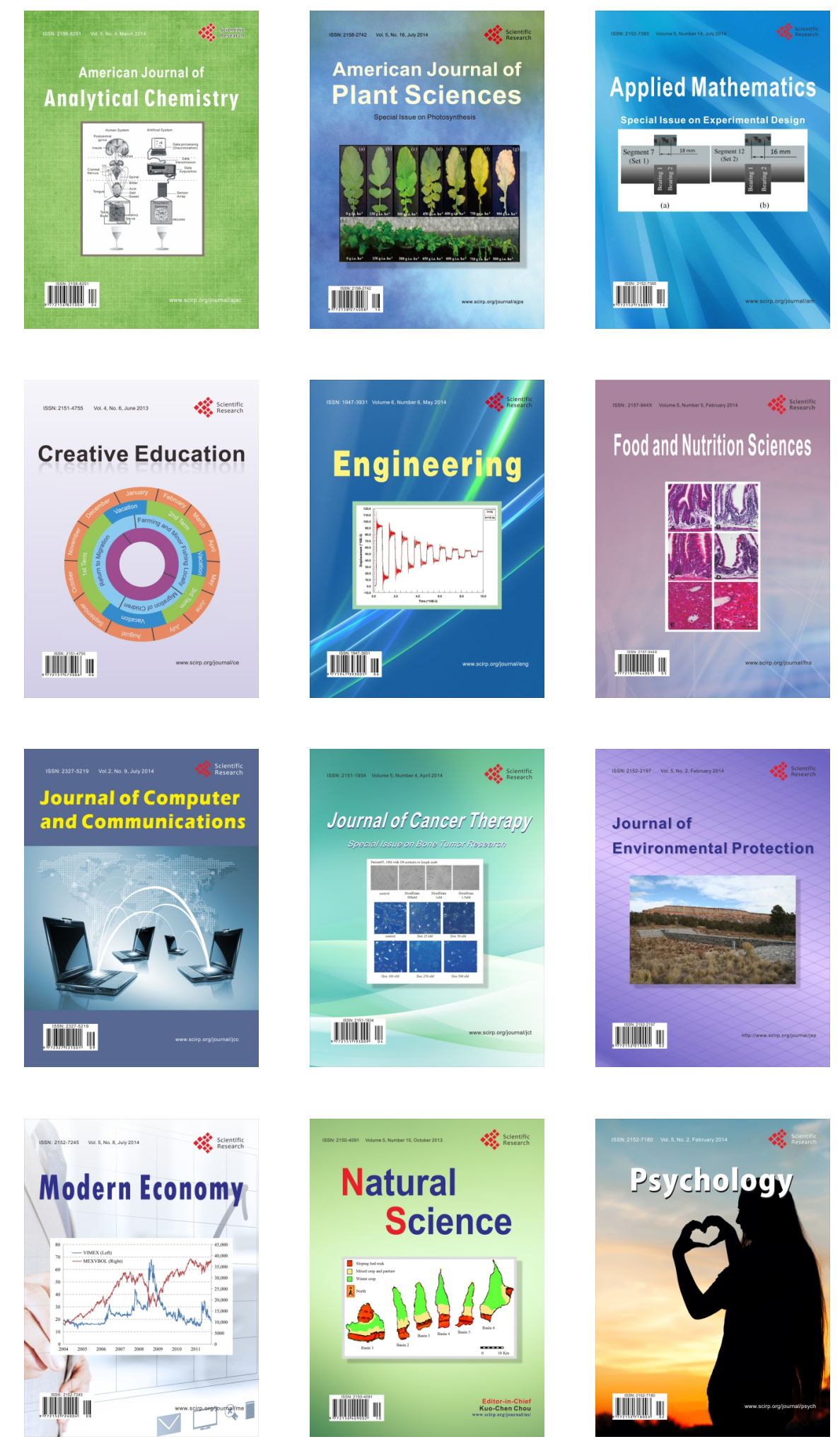